\title{
Genomic Survey of Bipolar Illness in the NIMH Genetics Initiative Pedigrees: A Preliminary Report
}

NIMH Genetics Initiative Bipolar Group: John I. Nurnberger, Jr.* (Chair), J. Raymond DePaulo, Elliot S. Gershon, Theodore Reich, Mary C. Blehar, and collaborators from Indiana University (Howard J. Edenberg, Tatiana Foroud, Marvin Miller, Elizabeth Bowman, Aimee Mayeda, N. Leela Rau, Carrie Smiley, and P. Michael Conneally), Johns Hopkins University (Francis McMahon, Deborah Meyers, Sylvia Simpson, Melvin McInnis, and O. Colin Stine), NIMH Intramural Research Program (Sevilla Detera-Wadleigh, Lynn Goldin, Juliet Guroff, Elizabeth Maxwell, Diane Kazuba, Pablo V. Gejman, Judith Badner, and Alan Sanders), and Washington University of St. Louis (John Rice, Laura Bierut, and Alison Goate).

Four sites collaborated with the NIMH to develop a resource for the genetic study of bipolar (BP) illness. Common methods of ascertainment and assessment were developed in 1989. A series of families with a bipolar I (BPI) proband and at least one BPI or schizoaffective, bipolar type (SA/BP) first-degree relative has been studied. We now report initial data from a genomic survey with an average intermarker interval of $10 \mathrm{cM}$ on 540 subjects from 97 families. This is the largest commonly ascertained and assessed linkage sample for bipolar illness reported to date; it includes 232 subjects with BPI, 32 SA/BP, 72 bipolar II (BPII), and 88 unipolar, recurrent (UPR). Nonparametric methods of analysis were employed, with all sites using affected sib pair analysis. The strongest findings thus far appear to be on chromosomes 1, 6, 7, 10, 16, and 22. Support has also been found for some previously reported linkages, including 21q and possibly Xq26. All these areas (as well as others) will be followed up with additional markers and further analyses. No locus tested thus far meets stringent criteria for an initial finding of significant linkage. Am. J. Med. Genet. 74:227-237, 1997. ๑ 1997 Wiley-Liss, Inc.

Contract grant sponsor: NIMH; Contract grant numbers: UOI MH46282, UOI MH54794, UOI MH46280, UOI MH54723, UOI MH46274, UOI 54701.

Material presented here does not necessarily reflect the opinions, official policy, or position of the National Institute of Mental Health.

*Correspondence to: Dr. John I. Nurnberger, Jr., Institute of Psychiatric Research, Department of Psychiatry, Indiana University School of Medicine, 791 Union Drive, Indianapolis, IN 462024887. Email: IDMI100@INDYVAX.IUPUI.EDU

Received 7 January 1997; Revised 12 March 1997

\section{KEY WORDS: bipolar affective disorder; ge- netics; linkage; genomic sur- vey; nonparametric analysis}

\section{INTRODUCTION}

Bipolar affective disorder (BP) is a disabling condition involving dysregulation of multiple physiologic functions, including mood, appetite, sleep, and activity [Goodwin and Jamison, 1990]. It occurs in about $1 \%$ of the population, with usual onset in young adulthood. With appropriate management the condition is substantially treatment-responsive, but episodes tend to recur throughout life. This condition has long been observed to aggregate within families [Nurnberger et al., 1994b]. Twin and adoption studies suggest significant heritable risk factors [Bertelsen et al., 1977; Mendlewicz and Rainer, 1977]. The genetics of BP illness is complex, with segregation analyses generally not consistent with single major locus inheritance [Nurnberger et al., 1994b]. No pathognomonic biochemical abnormality is currently known to be present, and diagnosis is based on clinical history and presentation.

Following the successful identification of linkage of Huntington disease to markers on chromosome 4 [Gusella et al., 1983], the interest of investigators in psychiatric genetics moved toward the application of molecular methods to the major psychiatric disorders. The paradigm for Mendelian disorders at that time was the identification of single large pedigrees with multiple cases of illness over several generations, and analysis of restriction fragment length polymorphism (RFLP) variation within the pedigree using the LOD score method. Egeland et al. [1987] reported linkage between $\mathrm{BP}$ and markers on chromosome 11p15 in a large Amish family. Subsequent studies in other samples, however, did not confirm this finding [DeteraWadleigh et al., 1987; Hodgkinson et al., 1987], and a later analysis in the same family, with additional clinical information and more markers typed, was not confirmatory [Kelsoe et al., 1989]. Still, interest continues 
in this region [Gurling et al., 1995], especially in the tyrosine hydroxylase locus [Leboyer et al., 1990; Todd and O'Malley, 1989].

$\mathrm{X}$ chromosome inheritance was first reported by Reich et al. [1969], and linkage to markers in the Xq28 region has been reported by some investigators [Mendlewicz and Fleiss, 1974; Mendlewicz et al., 1987; Baron et al., 1987; Bochetta et al., 1994] but not confirmed by other studies [Gejman et al., 1990; Berrettini et al., 1990; Baron et al., 1993]. A recent study of one large pedigree in Finland plus a review of published data has renewed interest in the $\mathrm{X}$ chromosome, showing positive findings in the $\mathrm{Xq} 26$ region [Pekkarinen et al., 1995].

Berrettini et al. [1997] reported linkage to an area on chromosome $18 \mathrm{p}$ near the centromere, using nonparametric analysis in 22 families. This was subsequently confirmed by Stine et al. [1995], who also reported linkage to an area on 18q. These authors also noted that the strength of each of these findings was dependent on the gender of the transmitting parent. The $18 q$ linkage is found primarily in families with apparent paternal transmission. The 18p linkage has been supported by data from Craddock et al. [1995] and Foroud et al. [1995]; Freimer et al. [1996] and deBruyn et al. [1995] also reported linkage on $18 \mathrm{q}$. It seems reasonable to postulate, at this time, that two or more genes on chromosome 18 may contribute to vulnerability to BP disorder. Recently, the Genetic Analysis Workshop included multiple submissions based on analysis of chromosome 18 data from 5 groups. Badner and Goldin [1996] reported substantial allele sharing in the $18 p$ region for the combined data set, as did Dorr et al. [1996]. However, Daly et al. [1996], using different analytic methods, could not confirm linkage.

Straub et al. [1993] reported linkage to markers on 21q; this was subsequently supported by DeteraWadleigh et al. [1997] and by Gurling et al. [1995]. Recent reports have also implicated areas on $4 \mathrm{p}$ [Blackwood et al., 1996], 5 [Coon et al., 1993], and 12 [Craddock et al., 1994; Barden et al., 1996]. Studies in the Amish identified several loci which may contain vulnerability genes, though none has met stringent criteria [Ginns et al., 1996; LaBuda et al., 1996].

Examples of successful detection of genes for complex disease in man are now available in studies of Alzheimer disease [Strittmatter et al., 1993; Scheuner et al., 1996], breast cancer [Castilla et al., 1994; Friedman et al., 1994; Simard et al., 1994], and type I diabetes [Davies et al., 1994]. These studies have shown the possibility of not only establishing linkage in complex disorders, but also of identifying vulnerability genes and analyzing them structurally and functionally.

The successful studies have relied on new analytic methods. Model-free methods, based on allele sharing at marker locations, have become more widely used than parametric LOD score method analysis for the study of complex disease, since genetic parameters are not readily quantifiable. Affected sib pair methods [Suarez et al., 1994; Blackwelder and Elston, 1985] are commonly used, with affected pedigree member (APM) methods [Weeks and Lange, 1988, 1992] conferring ad- ditional flexibility [see also Risch, 1990a-c]. These methods are not as powerful as the LOD score method for detecting major loci within pedigrees, but they are more robust to conditions of genetic heterogeneity and multifactorial inheritance. Allele sharing is assessed using identity by descent (IBD) methods whenever possible, since identity by state (IBS) measurements are subject to error due to allele frequency variation in different populations [Freimer et al., 1993]. Genotyping additional relatives beyond the affected pair may be useful, especially if both parents are not available [Gu et al., 1994]. Joint analysis of chromosomal segments, using multipoint methods, provides additional power for detection of linkage [Kruglyak et al., 1996]. Lander and Kruglyak [1995] proposed standards for evaluation of reported linkage to complex traits using such methods, but it is fair to say there is still much discussion in this area.

Recent studies have also utilized linkage disequilibrium methods [Escamilla et al., 1996] and family-based association methods such as the transmission disequilibrium test to narrow areas of linkage and evaluate candidate genes [Falk and Rubinstein, 1987; Spielman et al., 1993; Schaid and Sommer, 1994a,b; Thomson, 1995].

One particular category of candidate gene, those that contain trinucleotide repeats, has been of particular interest in neuropsychiatry, since an increased number of repeats is associated with vulnerability to illness in multiple conditions with behavioral manifestations [Ross et al., 1993]. Some of these conditions show "anticipation," i.e., decreasing age of onset or increasing clinical severity in succeeding generations, and such anticipation has been reported in BP [McInnis et al., 1993]. Increased numbers of repeats in BP have also been reported by one group [O'Donovan et al., 1995] using the repeat expansion detection method of Schalling et al. [1993].

As with analytic methods, laboratory methods have advanced considerably, with substantial reliance on highly variable (and thus informative) PCR-based microsatellite (simple sequence repeat) polymorphisms. Many laboratories are utilizing fluorescent rather than radioactive detection. The set of tetranucleotide markers from the Cooperative Human Linkage Center (CHLC) is often employed for easy readability. The above developments have influenced our choice of methods for the present study.

In 1988 the NIMH began a nationwide program to establish an archival resource for genetic studies in Alzheimer disease, schizophrenia, and bipolar illness. Following peer review, 10 sites were selected, 3 for Alzheimer, 3 for schizophrenia, and 4 for bipolar illness. The bipolar sites included Indiana University (John Nurnberger, P.I.), Johns Hopkins University (Raymond DePaulo, P.I.), the NIMH Intramural Research Program (Elliot Gershon, P.I.), and Washington University of St. Louis (Theodore Reich, P.I.). This group, together with collaborators and staff from the NIMH Extramural Research Division (Mary Blehar, David Shore, Darrell Kirch, Darrel Regier, Jane Steinberg, et al.) formed a Steering Committee to guide the progress of the group toward the formation of the national re- 
source, which was to include diagnostic information and transformed cell lines from members of multiple pedigrees with the conditions in question. The plan was to provide a living "library" of DNA and pedigree information, within which various hypotheses of transmission could be tested. Separate contracts were awarded by the NIMH for cell banking (Coriell Institute) and data management (SRA Associates), and these contractors have reported directly to Institute staff. This structure, involving multiple institutions operating in a highly interdependent manner, has proven sufficiently flexible to allow the goals of the program to be substantially achieved.

\section{PATIENTS AND METHODS}

The Bipolar and Schizophrenia groups of the Genetics Initiative met together regularly in order to develop a common ascertainment and assessment strategy. It was decided to ascertain probands systematically whenever possible, in order to maximize the generalizability of the study. For this reason, nonsystematic families were only accepted if they passed a higher threshold. Systematic families were ascertained by screening consecutive admissions at local treatment facilities; the majority of the families ascertained from three sites have been of this type (the Intramural Program has been unable to recruit in this way).

Standard diagnostic definitions for ascertainment and extension are the following: BPI and SA/BP are defined by DSMIII-R criteria; BPII and UPR by RDC with the modification that they both require recurrent episodes of depression. These criteria were devised to conform to the best clinical judgment of the investigators and to our reading of the literature as to which aspects of each syndrome are most important. Thus they do not conform to a single criterion system. BPI was regarded as the core diagnosis for study; DSMIII-R was in use and acceptable to all sites for this diagnosis. $\mathrm{SA} / \mathrm{BP}$ was regarded as closely related to BPI on the basis of data from Rice et al. [1987] and others [see summary in Gershon et al., 1988]. The diagnosis of BPII cannot be made in DSMIII-R, but is made in RDC. We additionally specified that depression be recurrent because of concerns about the reliability of hypomania and single-episode major depression [Rice et al., 1987]. RDC criteria were used for UPR for consistency with BPII and because they require functional impairment; modified RDC, used under some affected status models [Detera-Wadleigh et al., 1997], requires incapacitation or impairment in the major life role.

Rules for systematically ascertained BP families specified that: 1) the proband must have BPI and be admitted to one of the treatment facilities screened; 2) a secondary affected first-degree relative must be available, with either BPI or SA/BP; and 3) either the proband or secondary affected relative must have at least 2 living siblings 18 or older. The family of origin of the proband must not be bilineal (both parents with BPI or $\mathrm{SA} / \mathrm{BP}$ ). Nonsystematically ascertained families (located by advertisement, through advocacy groups, or through another source not a clinical series) were accepted if the family included 2 core phenotype individu- als (both with BPI, or one with BPI and one with SA/ $\mathrm{BP})$. The 2 core phenotype subjects were required to be first-degree relatives or second-degree relatives connected through a subject with BPII disorder. Two other affected individuals, including BPII and UPR as affected, were also required for the family to be accepted as nonsystematic. The additional affected individuals had to be living and closely related enough to be reachable by the extension rules (extension to all first-degree relatives of affected subjects; or extension through one unaffected to subjects with BPII, BPI, or SA/BP). Offspring of bilineal matings (both parents with BPI or $\mathrm{SA} / \mathrm{BP}$ ) were not included. Comorbid diagnoses were not a cause for exclusion of probands or other affected subjects within either systematic or nonsystematic families.

All subjects were assessed with the Diagnostic Instrument for Genetic Studies (DIGS) [Nurnberger et al., 1994a], including probands, first-degree relatives, and relatives reached by extension. Interviewers are generally clinically trained, and all undergo a special on-site training program consisting of observing and being observed in a series of interviews. The FIGS (Family Interview for Genetic Studies) is also administered to each subject. Each first-degree relative of the subject is inquired about individually, and more distant relatives are asked about as a group. Medical records are requested for all possible instances of inpatient and outpatient psychiatric treatment. The OPCRIT (Operational Criteria Checklist), which is largely scorable from items contained within the DIGS, is used to permit collaboration with the European Science Foundation. The DIGS itself is diagnosed by the interviewer and separately by an editor. Final diagnoses are made using a best-estimate procedure, combining all available information. Two clinicianreviewers make separate assessments of the data. The two reviewers discuss the case and agree on a diagnosis if possible (though disagreements are retained in the scoring); if no agreement is achieved, then a third clinician reviews all information, including the diagnoses of the first 2 reviewers, and reaches a final diagnosis.

A set of three hierarchical diagnoses was determined and used in all subsequent analyses. Under model I, an affected individual was one who was diagnosed with either schizoaffective, bipolar type (SA/BP) or bipolar I (BPI). Affected individuals under model II included those diagnosed under model I as well as those with bipolar II (BPII). Finally, model III included as affected all those in model II as well as those with unipolar recurrent depression (UPR).

We have followed the conclusions of Hodge [1992] in assessing bilineality. That is, information from offspring of bilineal matings adds power, though not as much as information from offspring of unilineal matings. We also anticipate that bilineal families will become particularly important in assessing gene interaction as confirmed linkages are identified. For this reason we did not exclude some families that might be bilineal. For ascertainment we excluded only offspring of model I matings. For the initial genotyping cohort we excluded offspring of model I or model II matings. We did not require that parents be interviewable in order 


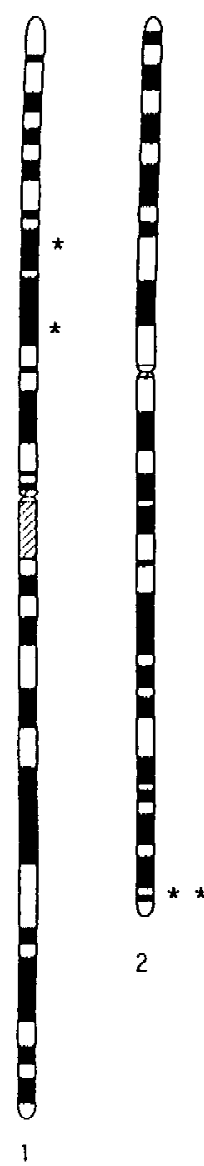

Initial Results from NIMH Bipolar

Genomic Survey - Model I
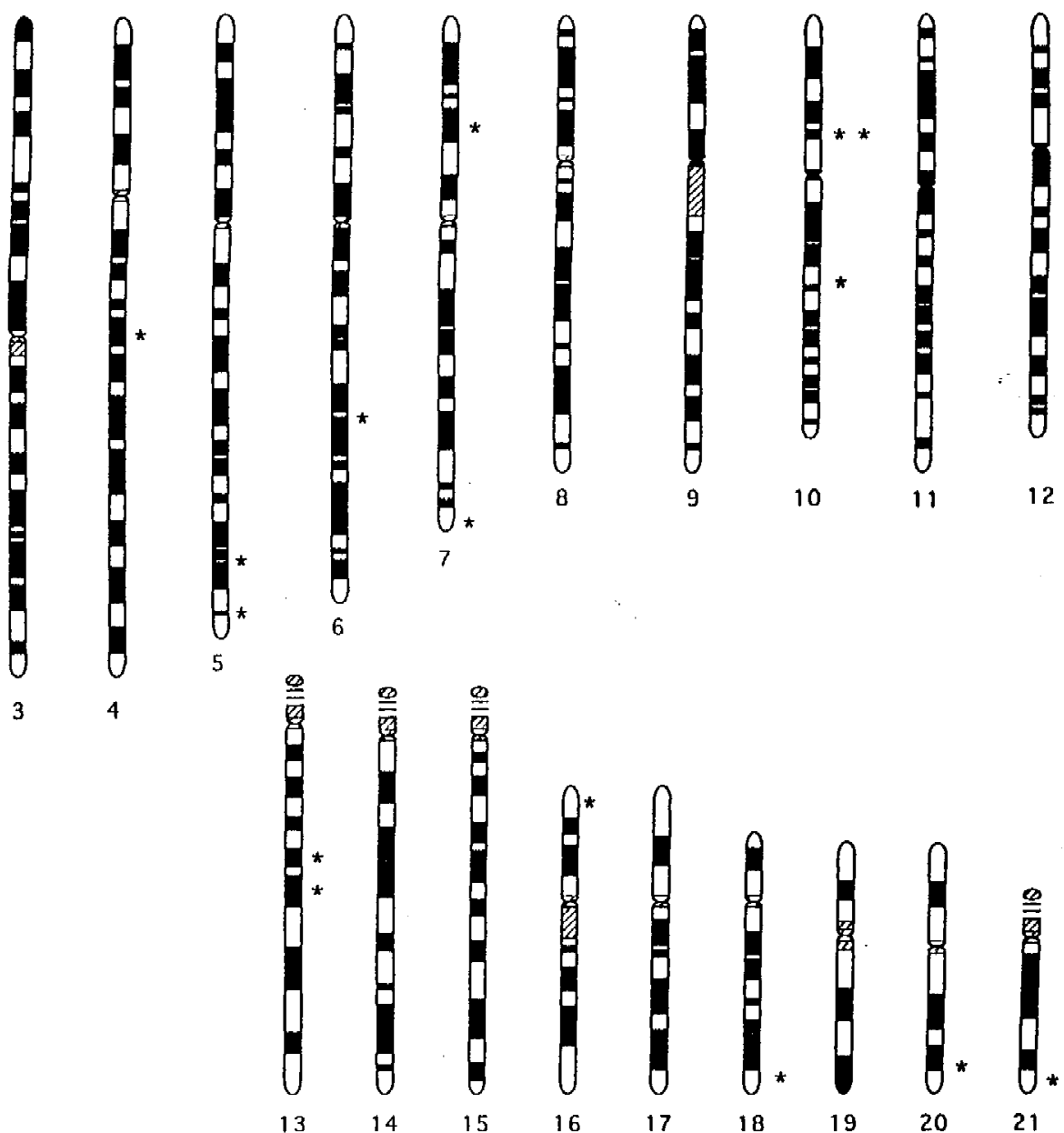

Fig. 1. Areas of interest from initial genomic survey of 97 families with multiple cases of bipolar illness using model I as affected (BPI and SA/BP). Allele sharing at $P<.05$, using SIBPAL (or MAPMAKER/SIBS for the $\mathrm{X}$ chromosome). **Allele sharing at the $P<.01$ level. Specific marker names and areas are noted in Table I.

to assess lack of affected status. And we did not exclude for more distant affected relatives on the "unaffected" side.

Simulations of the power of the sample were performed by Reich et al. [1969] using affected sib pairs from the first 91 families. Independent and interactive models were tested under which all of the genetic variance was accounted for by four loci (and thus at least one locus accounts for $25 \%$ or more of the variance). Under model II, the sample provided nearly $80 \%$ power to detect at least one of four independent loci at a LOD score of 1.0 , and $>90 \%$ power to detect one of four interactive loci with the same criterion. Parametric simulations by Dr. Foroud showed an expected mean LOD score of 1.6 for a dominant gene and 1.9 for a recessive gene under Model II assuming an alpha of 0.25. Thus a gene accounting for $25 \%$ of the variance in this dataset would likely be detectable at a level that would trigger further scrutiny.

By spring 1995, about 140 families with 1200 subjects had been ascertained. The material was reviewed by T. Foroud and others for informativeness for linkage. Five hundred and forty subjects were chosen from
97 families for genotyping. The initial genome screening panel was composed primarily of affected individuals. Individuals were considered affected if they met the requirements of any of the three models. Based on ascertainment criteria, the majority of families had at least one affected sib pair. However, additional family members were also collected, allowing the formation of other types of affected relative pairs. A series of rules was developed in order to genotype a consistent sample of individuals that would be composed mainly of affected sib pairs, but would also allow for identity by descent (IBD) estimation when possible.

All sib pairs with DNA and any of the four affected diagnoses were genotyped. When available, both biological parents were also genotyped. However, progeny of bilineal matings, defined as both parents with a model I diagnosis or one parent with a model I diagnosis and the other with a model II diagnosis, were not genotyped. Individuals affected under any of the three models were genotyped if they were part of an affected relative pair, such as avuncular, cousin, or grandparent-grandchild. However, the extent of genotyping common relatives varied according to the diagnosis of 
Initial Results from NIMH Bipolar Genomic Survey - Model II
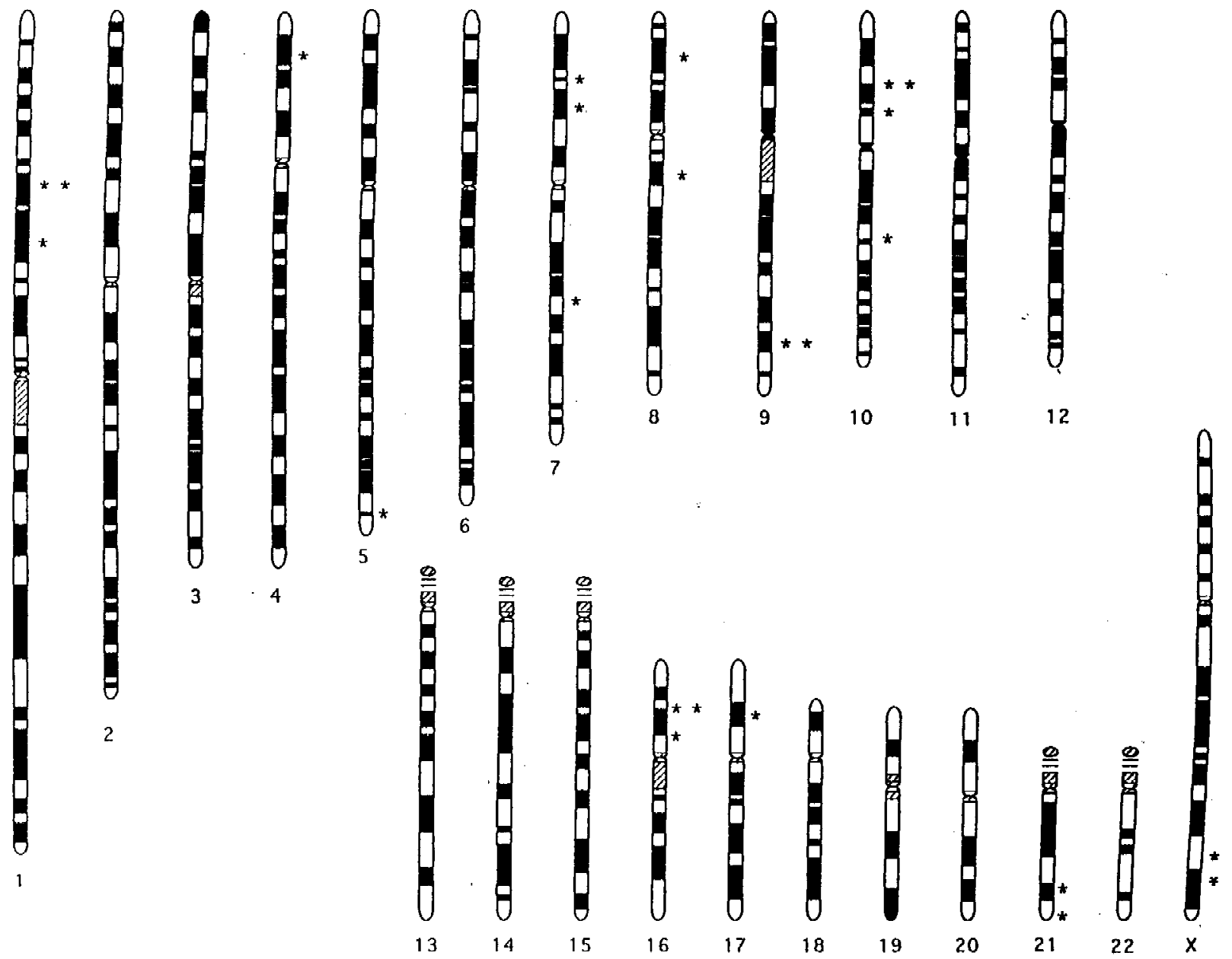

Fig. 2. Areas of interest from initial genomic survey of 97 families with multiple cases of bipolar illness using model II as affected (BPI, SA/BP, BPII). *Allele sharing at $P<.05$. **Allele sharing at $P<.01$. Specific marker names and areas are noted in Table I.

the individuals. If the individual who was not part of an affected sib pair was diagnosed with either $\mathrm{SA} / \mathrm{BP}$ or $\mathrm{BPI}$, then common relatives and their spouses were also genotyped in order to infer IBD sharing of alleles. If the affected individual who was not part of an affected sib pair had a diagnosis of BPII, then common relatives were also genotyped to allow for partial IBD inference. Finally, if the affected individual who was not part of an affected sib pair had a diagnosis of UPR, then no common relatives were genotyped and identity by state (IBS) would be inferred.

The final genotyping sample was composed of 32 individuals with SA/BP, 232 with BPI, 72 with BPII, 88 with MDDR, 71 with other diagnoses, and 45 never mentally ill. Under model I, there were 121 affected sib pairs (calculated as $n(n-1) / 2$ ), and 227 affected relative pairs. Model II contained 197 affected sib pairs and 324 affected relative pairs, and model III included 282 affected sib pairs and 412 affected relative pairs. Among the sib pairs, $46 \%$ had both parents included and an additional 35\% had one parent included; among the multisib groups, $31 \%$ had both parents included and an additional 39\% had one parent included.
DNA from these subjects was distributed to the laboratories at all sites, and genotyping began during November 1995 . The chromosomal assignments were divided among the laboratories, using as criteria a relatively even split of the genome and also each site's familiarity with certain chromosomes. Genotyping methods varied in the four laboratories [DeteraWadleigh et al., 1997; Edenberg et al., 1997; Rice et al., 1997; Stine et al., 1997]. Each marker was assessed for Mendelian inheritance, and families with large numbers of inconsistencies were reviewed for nonpaternity. Allele frequency estimation was performed using the USERM13 [Boehnke et al., 1991] program from the Mendel suite of linkage packages. Marker distances were estimated using CRIMAP [Green et al., 1990] and by consulting existing genomic data bases. Analytic methods also varied, but the minimum strategy included the SIBPAL program from S.A.G.E. [1994], used with half-sibs eliminated (since they are given excessive weight in the presently available version of the program). In this manuscript, results from the autosomes are presented using SIBPAL and results from the $\mathrm{X}$ chromosome using MAPMAKER/SIBS [see Stine 
Initial Results from NIMH Bipolar Genomic Survey - Model III

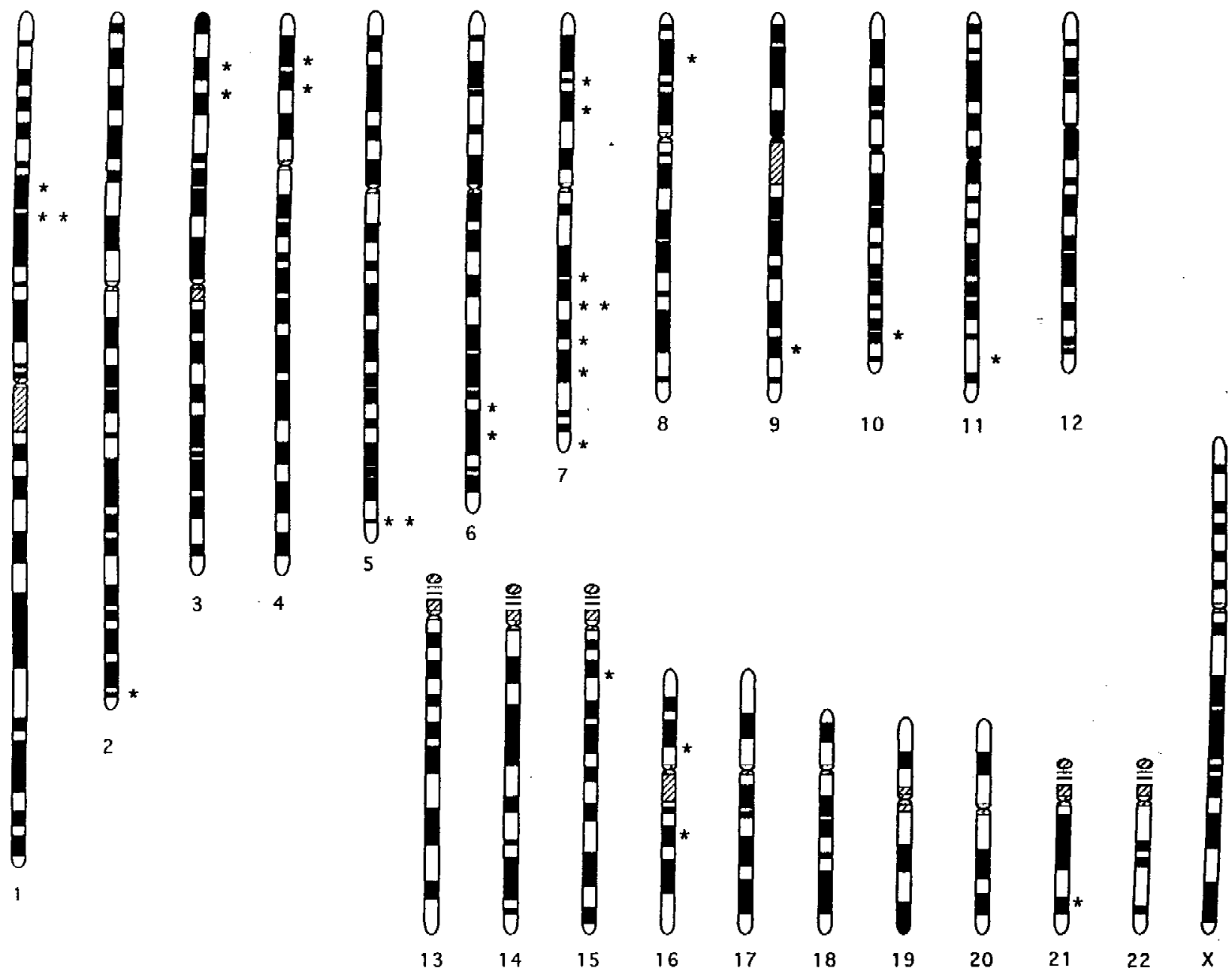

Fig. 3. Areas of interest from initial genomic survey of 97 families with multiple cases of bipolar illness using model III as affected (BPI and SA/BP, BPII, UPR). *Allele sharing at $P<.05$. **Allele sharing at $P<.01$. Specific marker names and areas are noted in Table 1.

et al., 1997]. One subject was ultimately dropped from the linkage data set because of familial inconsistencies in genotyping (though this DNA was included for allele frequency estimation).

A phenotypic data base for all subjects included in genotyping panels was maintained at Indiana University. The data base contained only best-estimate diagnoses using the criteria for ascertainment and extension (BPI and SA/BP by DSMIII-R; BPII with UPR and UPR by RDC). Affected status was coded using three hierarchical definitions: I, BPI and SA/BP; II, I and BPII; III, II and UPR. Additional definitions using modified RDC criteria were used by Detera-Wadleigh et al. [1997] to attempt replication of previously published findings on chromosomes 18 and 21 .

A genotypic data base for the three extramural sites was maintained at Washington University of St. Louis (J. Rice). NIMH Intramural has maintained its own genotypic data base. These data bases were maintained separately from the phenotypic data base. The two were only combined by the designated data analysts at each site, who did not participate in genotyping, gel scoring, or diagnosis.

\section{RESULTS}

Approximately 170,000 genotypes were generated, providing a survey of the genome with an average interval of $10 \mathrm{cM}$ (319 markers $\times 540$ subjects). Detailed results will be found in accompanying papers from the four participating laboratories [Detera-Wadleigh et al., 1997; Edenberg et al., 1997; Rice et al., 1997; Stine et al., 1997]. A summary of the results from SIBPAL, which was used in common by the four sites, is presented below. For the $\mathrm{X}$ chromosome we report the results of the total LOD calculated by MAPMAKER/ SIBS, though certain results may only be appreciated by examining gender-specific sharing [Stine et al., 1997]. For this summary, results with a nominal $P$ value of .05 or less will be reported, in order to convey the distribution of areas of interest for later follow-up. Only the standard (I-III) affection status models will be reported. Results are shown in Figures 1-4 and 
Selected Areas of Interest from NIMH Bipolar Genomic Survey
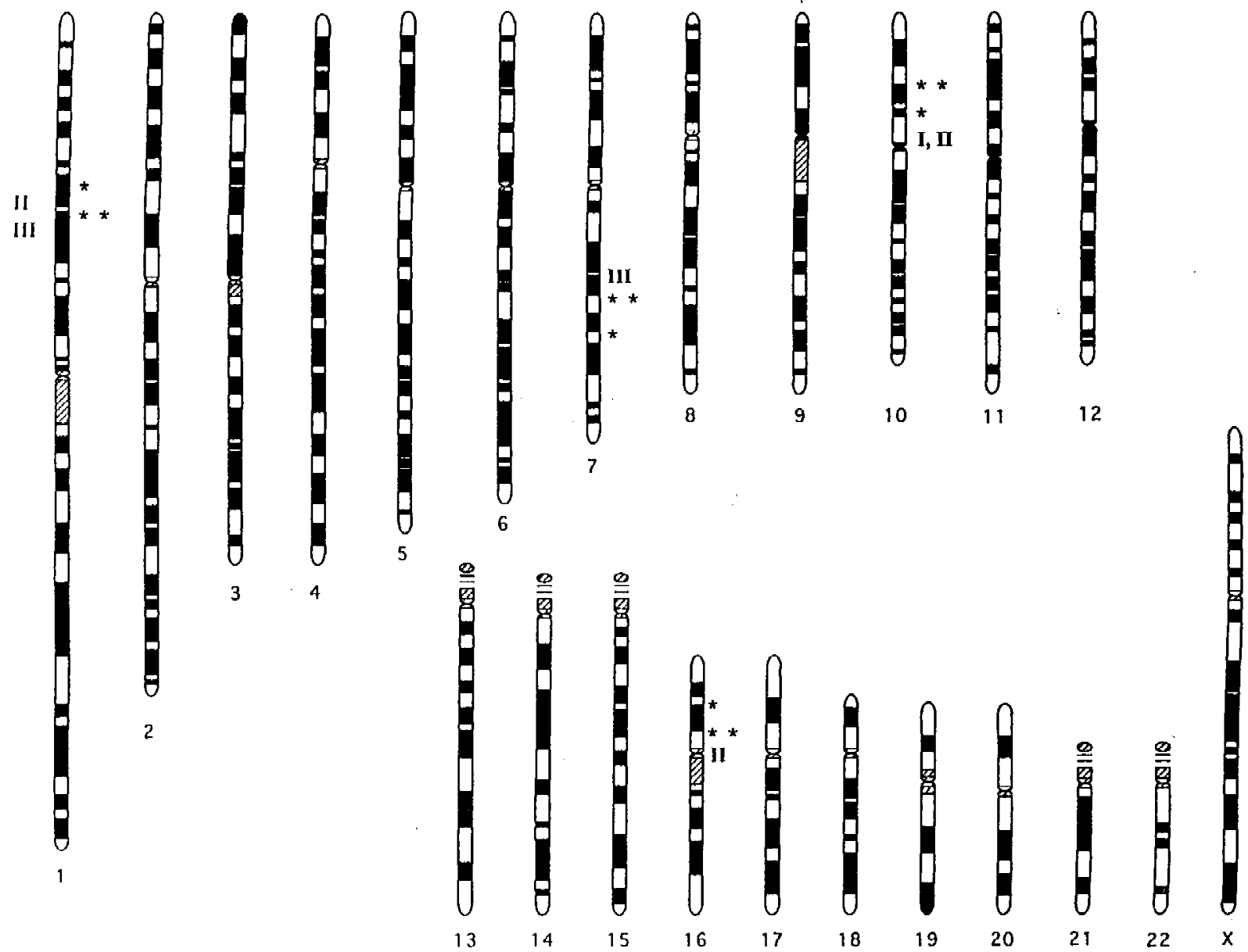

Fig. 4. Selected areas of interest from initial genomic survey of 97 families with multiple cases of bipolar illness. Areas highlighted are those where allele sharing is at $P<.01$ at one marker and $P<.05$ at a contiguous marker. Model I, II, or III is noted.

Table I. Areas with a nominal $P<.01$ by SIBPAL and a contiguous marker with $P<.05$ include 1) an area on chromosome 1 about $100 \mathrm{cM}$ from p-ter, 2) an area on $7 q$ near D7S524, 3) an area on 10p, and 4) an area on 16 near DGS2619. In addition we should note that positive findings on chromosomes $21 \mathrm{q}$ and $\mathrm{Xq} 26$ tend to support previous claims of linkage. Also, a newly identified area near D22S533 shows a maximum LOD of 2.46 with the ASPEX program [Edenberg et al., 1997], and several MOD scores $>2$ are found on the $q$ arm of chromosome 6 [Rice et al., 1997]. These latter findings are viewed as promising, though they did not meet the SIBPAL criterion noted above.

\section{DISCUSSION}

To our knowledge, this survey of 97 families, including 232 strictly diagnosed subjects with BPI disorder and their relatives, represents the largest genomic survey yet reported in major affective disorder. This sample is capable of detecting loci with a $\lambda$ (relative risk) of about 1.5 (i.e., a modest effect). The present report includes initial results from a first-pass genomic survey of this material conducted at an average 10-cM interval. This initial report concentrates on affected sib-pair analysis. Additional analytic techniques, including affected pedigree member analysis and LOD score analysis, will be performed and reported separately. The research plan involves identifying areas of interest and typing flanking markers for those areas. We will then identify and use an expanded set of samples in a second-pass genotyping that will pay particular attention to the identified areas of interest. An association panel will be identified to check candidate regions. We also intend to establish a consortium of investigators in BP illness to share information on candidate regions and speed the search for vulnerability genes.

Lander and Kruglyak [1995] calculate that in a full genomic survey one may expect 24 false-positive findings at the .05 level, $7-8$ at the .01 level, 1 at the .001 level, and .02 at the .0001 level. The present study involves an extensive genomic survey that nevertheless contains some gaps [Detera-Wadleigh et al., 1997; Edenberg et al., 1997; Rice et al., 1997; Stine et al., 1997] of 20-30 cM. Three affection status models (which are not independent) were tested. In these circumstances 44/301 markers showed allele sharing at the nominal significance level of $P<.05$. These markers 
TABLE I. Areas of Interest From SIBPAL Analysis of Genomic Survey Data From 97 Families With Bipolar Illness*

\begin{tabular}{|c|c|c|c|c|}
\hline Mode I & Model II & Model III & $\begin{array}{l}\text { Selected } \\
\text { areas }\end{array}$ & $\begin{array}{c}\text { Chromosomal } \\
\text { location }\end{array}$ \\
\hline \multirow[t]{2}{*}{ D1S224 } & D1S224 & D1S224 & D1S224 & $1 \mathrm{p} 31$ \\
\hline & & D1S1648 & D1S1648 & $1 \mathrm{p} 31$ \\
\hline D1S550 & D1S550 & & & $1 \mathrm{p} 31$ \\
\hline \multirow[t]{5}{*}{ D2S427 } & & D2427 & & $2 q 37$ \\
\hline & & D3S2403 & & $3 \mathrm{p} 24$ \\
\hline & & D3S3038 & & $3 \mathrm{p} 24$ \\
\hline & D4S2397 & D4S2397 & & $4 \mathrm{p} 15$ \\
\hline & & D4S391 & & $4 \mathrm{p} 14-15$ \\
\hline D4S1647 & & & & $4 q 22$ \\
\hline D5S820 & & & & $5 q 33$ \\
\hline D5S1456 & D5S1456 & D5S1456 & & $5 q 35$ \\
\hline \multirow[t]{4}{*}{ D6S474 } & & & & $6 q 22$ \\
\hline & & D6S1009 & & $6 q 23$ \\
\hline & & D6S1961 & & $6 q 24$ \\
\hline & D7S1802 & D7S1802 & & $7 \mathrm{p} 15$ \\
\hline \multirow[t]{5}{*}{ D7S1869 } & D7S1869 & D7S1869 & & $7 \mathrm{p} 14$ \\
\hline & & D7S524 & & $7 q 21$ \\
\hline & D7S1799 & D7S1799 & D7S1799 & $7 q 22$ \\
\hline & & D7S501 & D7S501 & $7 q 22-31$ \\
\hline & & D7S490 & & $7 q 31.3$ \\
\hline \multirow[t]{4}{*}{ D7S2195 } & & D7S2195 & & $7 q 36$ \\
\hline & D8S1106 & D8S1106 & & $8 \mathrm{p} 22$ \\
\hline & GATA12B06 & & & $8 q 12$ \\
\hline & D9S302 & D9S302 & & $9 q 33$ \\
\hline \multirow[t]{2}{*}{ D10S1423 } & D10S1423 & & D10S1423 & $10 \mathrm{p} 12$ \\
\hline & D10S1426 & & D10S1426 & $10 \mathrm{p} 12$ \\
\hline \multirow[t]{3}{*}{ D10S188 } & D10S188 & & & $10 \mathrm{q} 22$ \\
\hline & & D10S610 & & $10 \mathrm{q} 25$ \\
\hline & & GATA64D03 & & $11 q 23-24$ \\
\hline D13S800 & & & & $13 \mathrm{q} 21$ \\
\hline \multirow[t]{2}{*}{ D13S793 } & & & & $13 q 21$ \\
\hline & & GAAA1C11 & & $15 q 13-15$ \\
\hline \multirow[t]{5}{*}{ D16S2618 } & & & & $16 \mathrm{p} 13.3$ \\
\hline & D16S2619 & & D16S2619 & $16 \mathrm{p} 12$ \\
\hline & D16S749 & D16S749 & D16S749 & $16 \mathrm{p} 12$ \\
\hline & & D16S752 & & $16 q 13$ \\
\hline & D17S969 & & & 17p12 \\
\hline D18S70 & & & & $18 q 23$ \\
\hline \multirow[t]{3}{*}{ D20S173 } & & & & $20 q 13.2-13.3$ \\
\hline & D21S1254 & & & $21 q 22.1$ \\
\hline & D21S65 & D21S65 & & $21 q 22.1$ \\
\hline \multirow[t]{3}{*}{ D21S1255 } & & & & $21 \mathrm{q} 22.2$ \\
\hline & DXS1047 & & & $\mathrm{Xq} 26$ \\
\hline & GATA31E08 & & & Xq26-28 \\
\hline
\end{tabular}

*Markers showing allele sharing with nominal $P<.05$ in a genomic survey of 97 families with multiple cases of bipolar illness. Selected areas are those with nominal $P<.01$ at one marker and $<.05$ at a contiguous marker (see Fig. 4).

represent 34 areas distributed across the genome that bear further investigation. No area tested met the criteria of Lander and Kruglyak [1995] for suggestive or significant linkage on the basis of the present analyses. Likewise no previous finding in the literature may be said to be confirmed, using the criteria of these authors (reports meeting the initial significance criterion include Berrettini et al. [1994, 1997]; Blackwood et al. [1996]; Pekkarinen et al. [1995]; probably Freimer et al. [1996]; and possibly others). Nor can any genomic area be excluded given plausible assumptions about complex inheritance. In this combined data set, the absence of strong findings in individual linkage areas suggests that no single major locus accounts for as much as $50 \%$ of the variance in BP. A major locus accounting for $25 \%$ of the variance can be ruled out in some genomic areas but not in all [ Stine et al., 1997]. We note also that results herein should be interpreted in the light of statistical testing on the three affected status models. The three models have extensive overlap, and the tests are therefore not independent but partially independent. Likewise, the same data are scrutinized using several analytic methods. There is no clear way of correcting for these effects, which are common to many linkage analyses in human genetics.

It is notable that no positive linkage findings are seen on chromosome 18p. We regard the evidence for a locus on $18 p$ to be strong in other data sets. The fact that linkage is not evident in the analyses presented here probably reflects the difficulty of replicating findings in a complex disease, as noted by Suarez et al. [1994] among others. In fact, Sanders et al. (in prepa- 
ration) have identified a clone on $18 \mathrm{p}$ that shows association with BP illness in this sample, as well as in the sample described in Berrettini et al. [1991]. The evidence for a locus on $18 q$ continues to be substantial (McMahon et al., in preparation), and the modest allele sharing seen here on D18S70 tends to support that.

The area on $21 \mathrm{q}$ noted in this report is close to that found to be positive by Straub et al. [1993] (21q22.3), although it is not directly overlapping. The report by Detera-Wadleigh et al. [1996] finds allele sharing over a wide area that spans both the markers noted to be positive here as well as those in the report of Straub et al. [1993].

The allele sharing on Xq26 noted here may correspond to that reported by Pekkarinen et al. [1995]. However, the unusual property of this finding (sharing among sister-sister pairs, as noted by Stine et al. [this issue]) requires corroboration.

A $16 p$ region near that of the present report was implicated by Ewald et al. [1995]. However, no markers were used in common within the two studies and it is not possible to say that the same region is being identified.

Among other areas of interest, the 7q region was also mentioned by Detera-Wadleigh et al. [1994], based on early analyses of a separate pedigree series. Areas on 1 , 6,10 , and 22 do not appear to correspond to reports from previously published pedigree series. Nor do the areas on 6 and 22 appear to overlap with areas implicated in schizophrenia [Straub et al., 1995; Pulver et al., 1994].

We anticipate that further analysis of this family resource will clarify which of these loci should be pursued for specific genes. We welcome the participation of qualified investigators in further utilization of this data set, which is available through the NIMH as described on the World Wide Web (http://nimh. sratech.com).

\section{ACKNOWLEDGMENTS}

This work was supported by cooperative agreements between the sites and the NIMH (National Institute of Mental Health grants UOI MH46282, UOI MH54794, UOI MH46280, UOI MH54723, UOI MH46274, and UOI MH54701). The administrative support of Drs. Darrell Kirch, Steven Moldin, Darrel Regier, David Shore, and Jane Steinberg is gratefully recognized. Phenotypic data management was performed by David Kramer. Dr. James Trofatter helped develop the illustrations.

\section{REFERENCES}

Badner J, Goldin LR (1996): Bipolar disorder and chromosome 18: An analysis of multiple data sets. Pajaro Dunes Conference Center; Watsonville, CA, October 26-29, 1996. Genet Analysis Workshop 10:1-5.

Barden N, Plante M, Rochette D, Gagné B, Bordeleau L, Laberge C, Villeneuve A, Bouchard G, Morissette J (1996): Linkage and candidate loci for the psychoses: Emphasis on bipolar disorder. Psychiatr Genet 6: 145-146.

Baron M, Risch N, Hamburger R, Mandel B, Kushner S, Newman M, Drumer D, Belmaker K (1997): Genetic linkage between X-chromosome markers and bipolar affective illness. Nature 326:289-292.

Baron M, Freimer NF, Risch N, Lerer B, Alexander JR, Straub RE, Asokan
S, Das K, Peterson A, Amos J, Endicott J, Ott J, Gilliam TC (1993): Diminished support for linkage between manic depressive illness and $\mathrm{X}$-chromosome markers in three Israeli pedigrees. Nat Genet 3:49-55.

Berrettini WH, Goldin LR, Gelernter J, Gejman PV, Gershon ES, DeteraWadleigh S (1990): X-chromosome markers and manic-depressive illness. Rejection of linkage to Xg28 in nine bipolar pedigrees. Arch Gen Psychiatr 47:366-373.

Berrettini WH, Detera-Wadleigh S, Goldin L, Martinez M, Hsieh W, Hoehe M, Choi H, Muniec D, Ferraro T, Guroff J, Kazuba D, Harris N, Kron E, Nurnberger JI Jr, Alexander R, Gershon E (1991): Genomic screening for genes predisposing to bipolar disease. Psychiatr Genet 2:191208.

Berrettini WH, Ferraro TN, Goldin LR, Weeks DE, Detera-Wadleigh S, Nurnberger JI Jr, Gershon ES (1994): Chromosome 18 DNA markers and manic-depressive illness: Evidence for a susceptibility gene. Proc Natl Acad Sci USA 91:5918-5921.

Berrettini WH, Ferraro T, Goldin L, Detera-Wadleigh S, Choi H, Muniec D, Guroff J, Kazuba D, Nurnberger J, Hsieh W, Hoehe M, Gershon E (1997): A linkage study of bipolar illness. Arch Gen Psychiatry 54:27.

Bertelsen A, Harvald B, Hauge M (1977): A Danish twin study of manicdepressive disorders. Br J Psychiatry 130:330-351.

Blackwelder WC, Elston EC (1985): A comparison of sib-pair linkage test for disease susceptibility loci. Genet Epidemiol 2:85-97.

Blackwood DHR, He L, Morris SW, McLean A, Whitton C, Thomson M, Walker MT, Woodburn K, Sharp CM, Wright AF, Shibasaki Y, Clair DM, Porteous DJ, Muir WJ (1996): A locus for bipolar affective disorder on chromosome 4p. Nat Genet 12:427-430.

Bochetta A, Piccardi MP, Del Zompo M (1994): Is bipolar disorder linked to Xq28? Nat Genet 6:224.

Boehnke M (1991): Allele frequency estimation from data on relatives. Am J Hum Genet 52:1234-1249.

Castilla L, Couch F, Erdos M, Hoskins K, Calzone K, Garber J, Boyd J, Lubin M, Deshano M, Brody L, Collins F, Weber B (1994): Mutations in the BRCA1 gene in families with early-onset breast and ovarian cancer. Nat Genet 8:387-391.

Coon H, Jensen S, Hoff M, Holik J, Plaetke R, Reimherr F, Wender P Leppert M, Byerley W (1993): A genome-wide search for genes predisposing to manic-depression, assuming autosomal dominant inheritance. Am J Hum Genet 52:1234-1249.

Craddock N, Owen M, Burge S, Kurian B, Thomas P, McGuffin P (1994): Familial cosegregation of major affective disorder and Darier's disease (keratosis follicularis). Br J Psychiatry 164:355-358.

Craddock N, Nothen M, Parfitt E, Spurlock G, Holmans P, Fimmers R, Harris I, Lanczik M, Maier M, Reuner U, Gill M, Lim L, Vallada H, Collier D, Powell J, McGuffin P, Propping P, Owen M (1995): Linkage studies of bipolar disorder with chromosome 18 markers. Psychiatr Genet 5:16.

Daly M, Kirby A, Kruglyak L (1996): GAW10 summary: Analysis of bipolar chromosome 18 data. Pajaro Dunes Conference Center; Watsonville, CA, October 26-29, 1996. Genet Analysis Workshop 10:30-33.

Davies JL, Kawaguchi Y, Bennett ST, Copeman JB, Cordell HJ, Pritchard LE, Reed PW, Gough SCL, Jenkins SC, Palmer SM, Balfour KM, Rowe BR, Farrall M, Barnett AH, Bain SC and Todd JA (1994): A genomewide search for human type 1 diabetes susceptibility genes. Nature 371:130-136.

DeBruyn A, Souery D, Mendelbaum K, Mendelbaum K, Mendlewicz J, Van Broeckhoven C (1995): Positive linkage results with 18Q21.33-Q23 markers in a bipolar II family. Psychiatr Genet 5:16.

Detera-Wadleigh SD, Berrettini WH, Goldin LR, Boorman D, Anderson S, Gershon ES (1987): Close linkage of c-Harvey-ras and the insulin gene to affective disorder is ruled out in three Northern American pedigrees. Nature 325:806-808.

Detera-Wadleigh SD, Hsieh W, Berrettini W, Goldin L, Rollins D, Muniec D, Grewal R, Guroff J, Turner G, Coffman D, Barrick J, Mills K, Murray J, Donohue S, Klein D, Sanders J, Nurnberger JI Jr, Gershon E (1994): Genetic linkage mapping for a susceptibility locus to bipolar illness: Chromosomes 2, 3, 4, 7, 9, 10p, 11p, 22, and Xpter. Am J Med Genet 54:206-218.

Detera-Wadleigh SD, Badner J, Goldin L, Berrettini W, Sanders A, Rollins D, Turner G, Moses T, Haerian H, Muniec D, Nurnberger JI Jr, Gershon E (1996): Affected sib-pair analyses reveal support of prior evidence for a susceptibility locus for bipolar disorder on 21q. Am J Hum Genet 58:1279-1285.

Detera-Wadleigh S, Badner J, Yoshikawa T, Sanders A, Goldin L, Turner G, Rollins D, Moses T, Guroff J, Kazuba D, Maxwell M, Edenberg H, 
Foroud T, Lahiri D, Nurnberger JI Jr, Stine C, McMahon F, MacKinnon D, Simpson S, McInnis M, Depaulo R, Rice J, Goate A, Reich T, Blehar M, Gershon E (1997): Initial genome scan of the NIMH genetics initiative bipolar pedigrees: Chromosomes 4, 7, 9, 18, 19, 20, and 21 . Am J Med Genet, 74:254-262.

Dorr DA, Rice JP, Armstrong C, Reich T, Blehar M (1996): A meta-analysis of chromosome 18 linkage data for bipolar illness. Pajaro Dunes Conference Center; Watsonville, CA, October 26-29, 1996. Genet Analysis Workshop 10:44-48.

Edenberg H, Foroud T, Conneally M, Sorbel J, Carr K, Crose C, Willig C, Zhou J, Miller M, Bowman E, Mayeda A, Rau L, Smiley C, Stine C, McMahon F, DePaulo R, Meyers D, Rice J, Goate A, Reich T, DeteraWadleigh S, Goldin L, Gershon E, Blehar M, Nurnberger JI Jr (1997): Initial genomic scan of the NIMH genetics initiative bipolar pedigrees: Chromosomes 3, 5, 15, 16, 17, and 22. Am J Med Genet, 74:238-246.

Egeland JA, Gerhard DS, Pauls DL, Sussex JN, Kidd KK, Allen CR, Hofstetter AM, Housman DE (1987): Bipolar affective disorders linked to DNA markers on chromosome 11. Nature 325:783-787.

Escamilla M, Spesny M, Reus V, Gallegos A, Meza L, Molina J, Sandkuijl L, Fournier E, Leon P, Smith L, Freimer N (1996): Use of linkage disequilibrium approaches to map genes for bipolar disorder in the Costa Rican population. Am J Med Genet 67:244-253.

Ewald H, Mors O, Flint T, Koed K, Eiberg H, Kruse TA (1995): A possible locus for manic depressive illness on chromosome 16p13. Psychiatr Genet 5:71-81.

Falk K, Rubinstein P (1987): Haplotype relative risk. Ann Hum Genet 51:227-233.

Foroud T, Lahiri D, Guscar T, Bowman E, Mayeda A, Miller M, Rau L, Koller D, Smiley C, Conneally PM, Nurnberger JI Jr (1995): Chromosome 18 and bipolar affective disorder. Psychiatr Genet 5:17.

Freimer NB, Sankuijl LA, Blower SM (1993): Incorrect specification of marker allele frequencies: Effects on linkage analysis. Am J Hum Genet 52:1102-1110.

Freimer NB, Reus VL, Escamilla MA, McInnes LA, Spesny M, Leon P, Servico SK, Smith LB, Silva S, Rojas E, Gallegos A, Meza L, Fournier E, Baharloo S, Blankenship K, Tyler DJ, Batki S, Vinogradov S, Weissenbach J, Barondes SH, Sandkuijl A (1996): Genetic mapping using haplotype, association and linkage methods suggests a locus for severe bipolar disorder (BPI) at 18q22-q23. Nat Genet 12:436-441.

Friedman L, Ostermeyer E, Szabo C, Dowd P, Lynch E, Rowell S, King M (1994): Confirmation of BRCA1 by analysis of germline mutations linked to breast and ovarian cancer in ten families. Nat Genet 8:399 404.

Gejman PV, Detera-Wadleigh S, Martinez MM, et al. (1990): Manic depressive illness not linked to factor IX region in an independent series of pedigrees. Genomics 8:648-655.

Gershon ES, Hamovit J, Guroff JJ, Dibble E, Leckman JF, Sceery W, Targum SD, Nurnberger JI Jr, Goldin LR, Bunney WE Jr (1982): A family study of schizoaffective, bipolar I, bipolar II, unipolar and normal control probands. Arch Gen Psychiatry 39:1157-1167.

Gershon ES, DeLisi LE, Hamovit J, Nurnberger JI Jr, Maxwell ME, Schreiber J, Dauphinais D, Dingman CW II, Guroff JJ (1988): A controlled family study of chronic psychoses. Arch Gen Psychiatry 45:328336.

Ginns EI, Ott J, Egeland JA, Allen CR, Fann C, Pauls DL, Weissenbach J, Carulli JP, Falls KM, Keith TP, Paul SM (1996): A genome-wide search for chromosomal loci linked to bipolar affective disorder in the Old Order Amish. Nat Genet 12:431-435.

Goodwin FK, Jamison KR (eds) (1990): "Manic-Depressive Illness.” New York: Oxford University Press.

Green P, Lange K, Cox D (1990): Documentation for CRIMAP, version 2.4, Department of Genetics, School of Medicine, Washington University, St. Louis.

Gu C, Suarez BK, Todorov AA, Reich T (1994): A chromosome-based method to infer IBD scores for missing and ambiguous markers. Presented at the Genet Analysis Workshop.

Gurling H, Smyth C, Kalsi G, Moloney E, Rifkin L, O’Neill J, Murphy P (1995): Linkage findings in bipolar disorder. Nat Genet 10:8-9.

Gusella JF, Wexler NS, Conneally PM, Naylor SL, Anderson MA, Tanzi RE, Watkins PC, Ottina K, Wallace MR, Sakaguchi AY, Young AB, Shoulson I, Bonilla E, Martin JB (1983): A polymorphic DNA marker genetically linked to Huntington's disease. Nature 306:234-238.

Hodge SE (1992): Do bilineal pedigrees represent a problem for linkage analysis? Basic principles and simulation results for single-gene diseases with no heterogeneity. Genet Epidemiol 9:191-206.
Hodgkinson S, Sherrington R, Gurling H, Marchbanks R, Reeders S, Mallet J, McInnis M, Petursson H, Brynjolfsson J (1987): Molecular genetic evidence for heterogeneity in manic depression. Nature 325:805-806.

Kelsoe JR, Ginns EI, Egeland JA, et al. (1989): Re-evaluation of the linkage relationship between chromosome $11 \mathrm{p}$ loci and the gene for bipolar affective disorder in the Old Order Amish. Nature 342:238-243.

Kruglyak L, Daly M, Reeve-Daly M, Lander E (1996): Parametric and nonparametric linkage analysis: A unified multipoint approach. Am J Hum Genet 58:1347-1363.

LaBuda MC, Maldonado M, Marshall D, Otten K, Gerhard D (1996): A follow-up report of a genome search for affective disorder predisposition loci in the Old Order Amish. Am J Hum Genet 59:1343-1362.

Lander ES, Kruglyak L (1995): Genetic dissection of complex traits: Guidelines for interpreting and reporting linkage results. Nat Genet 11:241247.

Leboyer M, Malafosse A, Boularand S, Campion D, Gheysen F, Samolyk, Henriksson B, Denise E, DesLauriers A, Lepine JP, Zarifian E, Clerget-Darpoux F, Mallet J (1990): Tyrosine hydroxylase polymorphisms associated with manic-depressive illness. Lancet 335:1219.

McInnis MG, McMahon FJ, Chase GA, Simpson SG, Ross VA, DePaulo JR (1993): Anticipation in bipolar affective disorder. Am J Hum Genet 44:397.

Mendlewicz J, Fleiss JL (1974): Linkage studies with X-chromosome markers in bipolar (manic-depressive) and unipolar (depressive) illness. Biol Psychiatry 9:261-294.

Mendlewicz J, Rainer JD (1977): Adoption study supporting genetic transmission in manic-depressive illness. Nature 368:327-329.

Mendlewicz J, Simon P, Sevy S, Charon F, Bocas H, Legros S, Vassart G (1987): Polymorphic DNA marker on X chromosome and manic depression. Lancet 1:1230-1232.

Nurnberger JI Jr, Blehar MC, Kaufmann CA, York-Cooler C, Simpson SG, Friedman JH, Severe JB, Malaspina D, Reich T, Miller M, Bowman E, DePaulo R, Cloninger R, Robinson G, Mildin S, Gershon E, Maxwell E, Guroff J, Kirch D, Wynne D, Berg K, Tsuang M, Faraone S, Pepple J, Ritz AL (1994a): Diagnostic interview for genetic studies. Arch Gen Psychiatry 51:849-859.

Nurnberger JI Jr, Goldin LR, Gershon ES (1994b): Genetics of psychiatric disorders. In Winokur G, Clayton PJ (eds): "The Medical Basis of Psychiatry," 2nd ed. Philadelphia: W.B. Saunders, pp 459-492.

O'Donovan MC, Guy C, Craddock N, Murphy KC, Cardno AG, Jones LA, Owen MJ, McGuffin P (1995): Expanded CAG repeats in schizophrenia and bipolar disorder. Nat Genet 10:380-381.

Pekkarinen P, Terwilliger J, Bredbacka P, Lönnqvist J, Peltonen L (1995): Evidence of a predisposing locus to bipolar disorder on Xq24-q27.1 in an extended Finnish pedigree. Genome Res 5:105-115.

Pulver AE, Karayiorgou M, Wolyniec P, Lasseter VK, Kasch L, Nestadt G, Antonarakis S, Housman D, Kazazian HH, Meyers D, Ott J, Lamacz M Liang K, Hanfelt J, Ullrich G, DeMarchi N, Ramu E, McHugh PR, Adler L, Thomas M, Carpenter WT, Manschreck T, Gordon CT, Kimberland M, Babb R, Puck J, Childs B (1994): Sequential strategy to identify a susceptibility gene for schizophrenia: Report of potential linkage on chromosome 22q12-q13.1: Part 1. Am J Med Genet 54:3643.

Reich T, Clayton PJ, Winokur G (1969): The genetics of mania. Am J Psychiatry 125:1358-1369.

Rice J, Reich T, Andreasen NC, Endicott J, Van Eerdewegh M, Fishman R, Hirschfield RMA, Klerman GL: The familial transmission of bipolar illness. Arch Gen Psychiatry 44:441, 1987.

Rice J, Goate A, Williams J, Bierut L, Dorr D, Wu W, Shears S, Gopalakrishnan G, Edenberg H, Foroud T, Nurnberger JI Jr, DeteraWadleigh S, Goldin L, Guroff J, Gershon E, McMahon F, Simpson S, MacKinnon D, McInnis M, Stine C, DePaulo R, Blehar M, Reich T (1997): Initial genome scan of the NIMH genetics initiative bipolar pedigrees: Chromosomes 1, 6, 8, 10, and 12. Am J Med Genet, $74: 247-253$

Risch N (1990a): Linkage strategies for genetically complex traits. I. Multilocus models. Am J Hum Genet 46:222-228.

Risch N (1990b): Linkage strategies for genetically complex traits. II. The power of affected relative pairs. Am J Hum Genet 46:229-241.

Risch N (1990c): Linkage strategies for genetically complex traits. III. The effect of marker polymorphism on analysis of affected relative pairs. Am J Hum Genet 46:242-253.

Risch N, Botstein D (1996): A manic depressive history. Nat Genet 12:351353 . 
Ross CA, McInnis MG, Margolis RL, Li SH (1993): Genes with triplet repeats: Candidate mediators of neuro-psychiatric disorders. Trends Neurosci 16:254-260.

S.A.G.E. (1994): Statistical Analysis for Genetic Epidemiology, Release 2.2., Computer program package available from the Department of Epidemiology and Biostatistics, Case Western Reserve University, Cleveland.

Schaid DJ, Sommer SS (1994a): Comparison of statistics for candidategene association studies using cases and parents. Am J Hum Genet 55:402-409.

Schaid DJ, Sommer SS (1994b): Genotype relative risks: Method for design and analysis of candidate gene association studies. Am J Hum Genet 53:1114-1126.

Schalling M, Hudson TJ, Buetow K, Housman DE (1993): Direct detection of novel expanded, trinucleotide repeats in the human genome. Nat Genet 4:135-139.

Scheuner D, Eckman C, Jensen M, Song X, Citron M, Suzuki N, Bird TD Hardy J, Hutton M, Kukull W, Larson E, Levy-Lahad E, Viitanen M, Peskind E, Poorkaj P, Schellenberg G, Tanzi R, Wasco W, Lannfelt L, Selkoe D, Younkin S (1996): Secreted amyloid $\beta$-protein similar to that in the senile plaques of Alzheimer's disease is increased in vivo by the presenilin 1 and 2 and $A P P$ mutations linked to familial Alzheimer's disease. Nat Med 2:864-870.

Simard J, Tonin P, Durocher F, Morgan K, Rommens J, Gingras S, Samson C, Leblanc J, Bélanger C, Dion F, Liu Q, Skolnick M, Goldgar D, Shattuck-Eidens D, Labrie F, Narod S (1994): Common origins of BRCA1 mutations in Canadian breast and ovarian cancer families. Nat Genet 8:392-398.

Spielman RS, McGinnis RE, Ewens WJ (1993): Transmission test for linkage disequilibrium: The insulin gene region and insulin-dependent diabetes mellitus (IDDM). Am J Hum Genet 52:506-516.

Stine OC, Xu J, Koskela R, McMahon FJ, Gschwend M, Friddle C, Clark CD, McInnis MG, Simpson SG, Breschel TS, Vishio E, Riskin K, Feilotter H, Chen E, Shen S, Folstein S, Meyers D, Botstein D, Marr T, DePaulo R (1995): Evidence for linkage of bipolar disorder to chromosome 18 with a parent-of-origin effect. Am J Hum Genet 57:1384-1394.
Stine C, McMahon F, Chen L, Xu J, Meyers D, MacKinnon D, Simpson S, McInnis M, Rice J, Goate A, Reich T, Edenberg H, Foroud T, Nurnberger JI Jr, Detera-Wadleigh S, Goldin L, Guroff J, Gershon E, Blehar M, DePaulo R (1997): Initial genome screen for bipolar disorder in the NIMH genetics initiative pedigress: Chromosomes 2, 11, 13, 14 and X. Am J Med Genet, 74:263-269.

Straub RE, Lehner T, Loth JE, et al. (1993): Linkage analysis of bipolar affective disorder: Summary of genomic screening results and positive LOD scores with markers in region $21 q 22.3$ in one large family. Psychiatr Genet 3:3.

Straub RE, MacLean CJ, O’Neill AF, Burke J, Murphy B, Duke F, Shinkwin R, Webb BT, Zhang J, Walsh D, Kendler KS (1995): A potential vulnerability locus for schizophrenia on chromosome 6p24-22: Evidence for genetic heterogeneity. Nat Genet 11:287-293.

Strittmatter WJ, Saunders AM, Schmechel D, Pericak-Vance M, Enghild J, Salvesen GS, Roses AD (1993): Apolipoprotein E: High avidity binding to $\beta$-amyloid and increased frequency of type allele in late onset familial Alzheimer disease. Proc Nat Acad Sci USA 90:1997-1981.

Suarez BK, Hampe C, van Eerdewegh P (1994): Problems of replicating linkage claims in psychiatry. In Gershon ES, Cloninger CR (eds): Genetic Approaches to Mental Disorders, Proceedings of the 82nd Annual Meeting of the American Psychopathological Association, Inc. Washington, DC: American Psychiatric Press, pp 23-46.

Thomson G (1995): Control marker allele frequencies obtained from family data (the AFBAC method). Am J Hum Genet 57:487-498.

Todd RD, O’Malley KL (1989): Population frequencies of tyrosine hydroxylase restriction fragment length polymorphisms in bipolar affective disorder. Biol Psychiatry, 25:626-630.

Weeks DE, Lange K (1988): The affected-pedigree-member method of linkage analysis. Am J Hum Genet 42:315-326.

Weeks DE, Lange K (1992): A multilocus extension of the affectedpedigree-member method of linkage analysis. Am J Hum Genet 50: 859-868. 